\title{
The Global Dimension to Fiscal Sustainability
}

\author{
Joseph P. Byrne, Norbert Fiess ${ }^{*}$ and Ronald MacDonald \\ Department of Economics, University of Glasgow, Glasgow, Scotland, UK
}

$31^{\text {st }}$ March 2008

\begin{abstract}
This paper examines the issue of fiscal sustainability in emerging market countries and industrial countries. We highlight the importance of the time series properties of the primary surplus and debt, and find evidence of a positive long run relationship. Consequently we emphasise, that especially for emerging markets, it is important to recognise the implications of global capital market shocks for fiscal sustainability, a relationship which has hitherto been ignored in the empirical literature. Using a factor model we demonstrate that the relationship between deficit and debt is conditional upon a global factor and we suggest that this global factor is related to world-wide liquidity. We also demonstrate that this acts as a constraint on emerging market economies' fiscal policy.
\end{abstract}

Keywords: Fiscal Policy; Sustainability.

JEL Codes: E62; F34; H62; H63.

\footnotetext{
${ }^{*}$ Correspondence Address: University of Glasgow, Department of Economics, Adam Smith Building, Glasgow, G12 8RT, United Kingdom. Email: <n.fiess@lbss.gla.ac.uk>. Tel: +44(0)141 330 5683. Fax: +44 (0)141 330 4940. For their comments and other discussions the authors would like to thank without implicating seminar participants at the World Bank, Washington and SIRE Conference on Economic and Financial Linkages in the University of Glasgow. In particular, Marco Bassi, Aleksander Berensten, Nina Budina, Giorgio Fazio, David Hendry, Søren Johansen, Alexandros Kontonikas, Farhad Noorbakhash and Brian Pinto.
} 


\section{Introduction}

Financial globalization has resulted in the greater availability of liquidity in international capital markets and this has led to various booms, and busts, in capital flows. For example, new capital became available following the oil boom of the 1970s, when the accumulation of so-called petrodollars made international banks highly liquid and eager to finance public debt in emerging markets, most notably in Latin America. Financial liberalisation and the capital flows of the 1970s and early 1980s preceded the debt crisis that started in Mexico in 1982. To solve this crisis, and instrumental for the development for emerging markets' bond markets, sovereign debt was securitize with the Brady Plan. Industrial countries since the 1970s have pursued policies of fiscal consolidation and sovereign debt has been less dependent upon capital flows (see Hauptmeier et al. 2006, and Favero and Giavazzi, 2007). In contrast, there is a close link between financial globalization and the fiscal sustainability of emerging market economies: emerging markets rely on foreign capital inflows to finance sovereign debt. ${ }^{1}$

A troublesome aspect of financial globalization is that it has coincided with a high degree of instability, both of capital flows and domestic financial systems. Sudden Stops in the availability of external finance due to abrupt changes in investor sentiment towards emerging markets have greatly increased the vulnerability of these countries (Calvo, 1998). In particular, the Mexican Crisis 1994, East Asian Crisis of 1997-98 and the Russian Crisis of 1998 revealed the volatile nature of capital flows as sudden reversals in international capital flows forced painful macroeconomic

\footnotetext{
${ }^{1}$ The emergence of large sovereign wealth funds in particularly Asia as well as the 2007 US subprime crisis highlight further linkages between financial globalization and fiscal sustainability, which may well become more apparent in the future. Through sovereign wealth funds in emerging markets are increasingly taking exposure to corporate risk in industrial countries, which creates a contingent fiscal liability for the government. The nationalization of the distressed Northern Rock mortgage bank in the UK in 2007, which was one of the first victims of the subprime mortgage crisis outside the US, created an off-balance sheet fiscal liability for the UK government.
} 
adjustments in most emerging market economies. Contagion, financial globalization's "evil twin", further ensured that the pain was not only felt by countries at the epicentre of the crises, but throughout global capital markets.

The inability and/or reluctance of emerging market countries to issue debt in domestic currency fostered a close link between global capital markets and domestic debt and this is identified in the literature on Original Sin and Debt Intolerance. ${ }^{2} \mathrm{~A}$ large share of public debt in emerging markets is denominated in foreign currency and of short-maturity. The vulnerability of fiscal sustainability in emerging markets to adverse external shocks has been widely studied (see inter alia Reinhart, Rogoff and Savastano, 2003, Kaminsky, Reinhart and Végh, 2004, Calvo, Izquierdo and Talvi, 2003).

Emerging market sovereign bond spreads increased sharply across the board following the 1998 Russian Crisis, when global liquidity temporarily vanished. During 2002 and 2007 there has been a surge in global liquidity: capital flows recovered and emerging market sovereign bond spreads reached record lows. The easing of financing constraints of emerging market economies lead to a general improvement of fiscal sustainability in emerging markets, see Hauner and Kumar $(2005) .^{3}$

As global market conditions impact fiscal sustainability in emerging markets, it appears that a significant part of debt dynamics in emerging markets are beyond the direct control of domestic policy makers. A sudden stop increases the cost of capital for emerging market borrowers, while a surge in global liquidity makes capital cheap.

\footnotetext{
${ }^{2}$ For the literature on Original Sin see Eichengreen and Hausmann (1999) and for Debt Intolerance see Reinhart, Rogoff and Savastano (2003).

${ }^{3}$ Hauner and Kumar (2005) argue that in recent years financial globalization and benign global market conditions have helped emerging markets in their external financing and budgetary positions. They argue that benefits from the benign environment have been substantial, but point out that the potential reversal of the favourable external conditions underlines the need for further fiscal reforms.
} 
Unless emerging market governments reduce their dependence on foreign capital inflows by borrowing in domestic currency or reducing borrowing altogether through fiscal reform, fiscal sustainability remains subject to global liquidity shocks.

As debt problems have been at the centre of many recent crises in emerging markets, debt sustainability analysis has become standard practice when assessing macro economic policy. The Present Value Constraint (PVC), or Intertemporal Budget Constraint (IBC) approach, is often used to assess fiscal sustainability in empirical studies. Fiscal policy is deemed sustainable, when the continuation of past policies would keep future debt accumulation under control. Since Hamilton and Flavin (1986) the PVC, equivalent to the Non-Ponzi game, or transversality, condition has been tested using time series econometrics in numerous studies (e.g. Hamilton and Flavin, 1986, Hakkio and Rush, 1991, Trehan and Walsh, 1991, MacDonald, 1992, Ahmed and Rogers, 1995, Quintos, 1995, Mendoza and Ostry, 2006 and Arghyrou and Luintel, 2007). In particular, Trehan and Walsh (1991) is of interest in what follows since they emphasize the relationship between primary surplus and debt.

However, Bohn (2007) provides a substantial challenge to the time series literature on fiscal policy. Specifically, Bohn suggested that rejections of stationaritybased sustainability tests are invalid because in an infinite sample, any order of integration of debt is consistent with the transversality condition which implies that intertemporal budget constraint is always satisfied. Instead, Bohn (2007) emphasizes whether a country's primary surplus responds positively to debt as an indicator of sustainability. As in Bohn (1998) this depends upon the assumption that the series are stationary. For them to be related in a statistical sense when they are nonstationary, they must be of the same order of integration and primary surplus and debt must be cointegrated. We seek to shed light on this issue for industrial and emerging market 
economies in a panel context. In particular, we avoid difficulties in our panel, with nonstationary common factors leading to a spurious regression problem, by adopting a principal components approach (see Bai, Kao and $\mathrm{Ng}$, 2007). However, if these principal components are nonstationary they break the link, emphasized by Bohn (2007), between primary surplus and debt and hence suggest fiscal policy may have other preoccupations.

The main focus of our work is on fiscal sustainability issues in emerging market countries and for this purpose we exploit a panel data set for 27 emerging markets over the period 1990 and 2005. We also analyze debt sustainability for 15 industrial countries for a longer sample spanning the period of 1978 and 2005 (the longer data period is not available for the emerging market countries). We see the industrial country panels as providing a 'control' set of results by which the emerging market results may be compared and which are not susceptible to small $T$. Our results may be summarised as follows. For our emerging market economies, we find that a global factor is the key to explaining fiscal sustainability, and we find that this factor is nonstationary and can be identified as a global liquidity effect: while a surge in capital inflows eases public sector financing constraints, a sudden stop increases the cost of external financing and debt service. The nonstationarity of this factor would seem to be bad news for policy makers in emerging markets: while fiscal positions have greatly improved with the recent surge in global liquidity, and new global credit crunch could bring a rapid deterioration of public finances. We also uncover this global factor in the fiscal response of industrial countries, however there is are marked difference: while a global liquidity shock affects the fiscal response of industrialized countries, it neither dominates nor takes away industrialised countries' ability to 
smooth the business cycle; much in contrast, emerging market economies do not appear to have room for such welfare enhancing policies.

This paper is organized as follows. In the next section we provide a brief literature review. In section 3 we outline our methodology. Section 4 presents data and results for nonstationary panel estimation and evidence of panel cointegration, based on nonstationary factors. Section 5 identifies the nonstationary factor. Section 6 provides some robustness analysis and section 7 concludes.

\section{Literature Review}

In this section we review research directly related to our times series approach to fiscal sustainability. Firstly, however, we set out the Government Budget Identity:

$$
G_{t}+\left(1+i_{t}\right) B_{t-1}=T_{t}+B_{t}
$$

where $G_{t}$ is the level of government primary expenditure (i.e. excluding interest payments), $i_{t}$ is the interest rate, $B_{t}$ is the debt level, and $T_{t}$ is the level of government tax revenue. We can consequently express the level of debt as follows, where $\theta_{t}=$ $1 /\left(1+i_{t}\right)$

$$
B_{t}=\theta_{t}\left(T_{t+1}-G_{t+1}+B_{t+1}\right)
$$

By repeated substitutions, assuming a constant future interest rate and solving forward, the Intertemporal Budget Constraint (IBC) can be derived, which is equivalent to the expected present value constraint:

$$
B_{t}=\sum_{i=1}^{\infty} \theta^{i} E_{t}\left(T_{t+1}-G_{t+1}\right)
$$

which will hold as long as the following transversality (no Ponzi games) condition is satisfied 


$$
\lim _{n \rightarrow \infty} \theta^{n} E_{t}\left(B_{t+n}\right)=0
$$

These conditions have served as the benchmark in the empirical literature on sustainability. Hamilton and Flavin (1986), for example, examine whether the null hypothesis of a unit root for the real stock of debt and the primary surplus can be rejected and, hence, whether debt trends stochastically, and is hence unsustainable (i.e. the transversality condition is satisfied). They find that the debt unit root hypothesis can be rejected for the period 1962-1984 and that the data is consistent with the idea that the budget is perceived by investors as being balanced in present value terms. ${ }^{4}$

Hakkio and Rush (1991) suggest that cointegration between real government revenue and real government spending (inclusive of real interest rate payments) is a necessary condition for the intertemporal budget constraint to be satisfied. They find evidence of cointegration for the US (from 1950-1988), although evidence is less clear cut for a later sample (1976-1988), which suggests violation of the government's intertemporal budget constraint. ${ }^{5}$ Trehan and Walsh (1991) emphasize that with constant expected real interest rates a necessary and sufficient test of the intertemporal budget constraint is cointegration of debt and the primary surplus and a quasidifference stationary primary surplus. Intuitively, if primary surplus and debt are cointegrated the government has some concern with debt levels when deciding fiscal policy.

Ahmed and Rogers (1995) consider the present value constraint for the US and the UK, by examining a cointegrating vector that includes $G_{t}$ and $T_{t}$. Using over a hundred years of annual data and, taking account of breaks using dummies in the

\footnotetext{
${ }^{4}$ The test statistics reject the null of unit root only very marginally and suffer from serial correlation according to Kremers (1988).

${ }^{5}$ However, Hakkio and Rush (1991) fail to find evidence of cointegration between government spending and government revenue, when they are normalised by GDP.
} 
estimated relationship, they find evidence that the constraint holds. Ahmed and Rogers (1995) also indicate that $G_{t}$ and $T_{t}$ are difference stationary, even taking account of Perron (1989) type breaks. Quintos (1995) makes a distinction between weak and strong forms of sustainability, where weak sustainability is some relationship between government spending and revenue without evidence of cointegration, and strong sustainability is a one-to-one relationship and the existence of a cointegrating relationship. In this context, no relationship between spending and revenue suggests fiscal policy is unsustainable. ${ }^{6}$

However, to our knowledge, none of the above-noted studies consider the interrelationships between global capital markets and fiscal sustainability. If global shocks matter for fiscal sustainability, tests of fiscal sustainability in a panel setting that do not fully account for any cross-sectional dependence are likely to yield the wrong conclusions. Cross-sectional dependency, which if not accounted for, leads to size distortion in standard panel unit root tests, and therefore presumably cointegration tests, which bias them towards the alternative hypothesis of stationarity (see O’Connell, 1998, Andrews, 2005, and Breitung and Pesaran, 2007).

Bohn (2007) recently levied a further criticism of sustainability tests based on unit root testing and cointegration. Specifically, Bohn (2007) suggested that rejections of sustainability based on stationarity and cointegration tests are invalid because in an infinite sample, any order of integration of debt is consistent with a transversality condition, which in turn implies that intertemporal budget constraint is always satisfied. Bohn $(1998,2007)$ argues that more emphasis should be put on the economics of the IBC and proposes an alternative means of testing the sustainability of fiscal policy, based on the responsiveness of the primary surplus to the debt-GDP

\footnotetext{
${ }^{6}$ See also Davig and Leeper (2005) and Thams (2007) for empirical evidence examining fiscal rules using Markov Switching methods.
} 
level, where a positive response parameter is seen as consistent with fiscal probity. ${ }^{7}$ Equation (1) can be rearranged to give the ratio of primary surplus to GDP, $\left(T_{t}-\right.$ $\left.G_{t}\right) / Y_{t}$, as a function of the debt to GDP ratio, $B_{t} / Y_{t}$.

$$
\frac{T_{t}-G_{t}}{Y_{t}}=(i-g) \frac{B_{t-1}}{Y_{t-1}}
$$

Where $g$ is the growth rate of nominal GDP. Expressing $s_{i t}$ as the primary surplus (i.e. taxes minus non-interest spending), $b_{i t}$ is the debt level (both variables are ratios of GDP) and assuming $b_{i t}=b_{i t-1}$ in the long run and $u_{i t}$ is a stationary residual error, our approach to examining fiscal probity is to estimate equation (6) in a panel time series setting using the following regression:

$$
s_{i t}=\alpha_{i}+\rho b_{i t}+\gamma \mathrm{Z}_{i t}+u_{i t}
$$

If $\rho>0$, this is indicative of fiscal probity on the part of the government. Any increase in debt is reflected in an increase in the fiscal surplus of the government. Additionally equation (6) includes other potential determinants $\left(Z_{i t}\right)$ of the primary surplus, but if these are stationary while we have a cointegrating relationship between primary surplus and debt, superconsistency would suggest we can ignore $Z_{i t}{ }^{8}$ Furthermore a panel approach to estimating equation (6) assumes that the regression error terms $\left(u_{i t}\right)$ are cross sectionally independent. To the extent that $u_{k t}$ and $u_{j t}$ are not independent, $\forall k \neq j$, and this correlation can be represented by a global stochastic trend, then a Bohn reaction function which ignores a nonstationary factor may be based on a spurious panel regression (see Bai, Kao and $\mathrm{Ng}$, 2007). In the next section we discussion how we deal with this issue.

\footnotetext{
${ }^{7}$ We should also highlight that Bohn does not preclude the importance of a nonstationary debt dynamic in finite samples, which would highlight the importance of the time series properties of the fiscal variables. Indeed Bohn (1998) argues that for a century of US data primary surplus and debt are stationary and that they are positively related.

${ }^{8}$ For a discussion of superconsistency see Stock (1987) and the discussion in Bohn (1998) for the stationary case.
} 
In sum, while we agree with Bohn's (2007) critique of the use of purely time series methods to test the IBC, we nonetheless believe time series properties of the data can not be completely ignored and can provide a useful testing mechanism especially when other factors which may have an important bearing on a test of fiscal sustainability are brought to bear. In our study we believe that the interrelationship between fiscal sustainability and the globalisation of international capital markets is a crucial one. To account for common shocks to fiscal sustainability, which make standard least squares inconsistent due to induced spurious regression problem from unobserved stochastic trends, we apply, in particular, the Bai, Kao and $\mathrm{Ng}$ (2007) panel cointegrating regression estimator which deals with cross sectional correlation by utilising a factor model approach. We therefore see our approach as in the spirit of Bohn $(1998,2007)$ who advocated estimating primary surplus response functions.

\section{Econometric Methods}

In this paper we utilise nonstationary time series methods to explore the relationship between the primary surplus and debt and a factor model to elaborate the importance of global capital market shocks in explaining the lack of fiscal sustainability in emerging markets. Specifically, we test for a unit root in the variables using the Bai and Ng (2004) PANIC test, and use panel time series estimators from Bai and Kao (2006) and Bai, Kao and $\mathrm{Ng}$ (2007) to test the primary surplus relationships. The former estimator adjusts for cross sectional correlation using a stationary factor, whilst the latter contains a nonstationary factor. We now sketch our empirical methods. 


\subsection{PANIC Panel Unit Root Test}

The PANIC approach introduced by Bai and Ng (2004) uses a factor structure to understand the nature of nonstationarity in large dimensional panels. The Bai and $\mathrm{Ng}$ factor model is set out for the case where only an intercept is included:

$$
\begin{aligned}
& y_{i t}=c_{i}+\lambda_{i}^{\prime} F_{t}+e_{i t}, \\
& F_{t}=\alpha F_{t-1}+u_{t}, \\
& e_{i t}=\rho_{i} e_{i t-1}+\varepsilon_{i t} .
\end{aligned}
$$

The series $y_{i t}$ is the sum of a cross section specific constant $\left(c_{i}\right)$, a common component $\lambda_{i}^{\prime} F_{t}$ and an error, $e_{i t}$, which is the idiosyncratic component. The series $y_{i t}$ is nonstationary if the common factors are nonstationary $(\alpha=1$, in equation (8)) and/or the idiosyncratic component $\left(\rho_{i}=1\right.$, in equation (9)) are nonstationary. The PANIC method allows us to identify whether nonstationarity is pervasive (due to the common factor) or series specific (due to the individual series). Whether there is a factor or not is identified by an information criteria, see Bai and $\mathrm{Ng}$ (2002). Unlike Moon and Perron (2004) and Pesaran (2007), the PANIC test does not assume that only the idiosyncratic component can have a unit root. In the present application, it is particularly useful that PANIC determines explicitly whether the nonstationarity in a series is pervasive or variable-specific.

We make use of two test statistics from Bai and Ng (2004). Firstly, an Augmented Dickey Fuller test on the common factor $\left(A D F_{\hat{F}}^{c}\right)$ and secondly a Fishertype pooled ADF test on the idiosyncratic individual errors $\left(A D F_{\hat{e}}^{c}(i)\right)$. Bai and $\mathrm{Ng}$ (2004) suggest the test statistic on the idiosyncratic element is distributed as standard normal as follows: 


$$
P_{\hat{e}}^{c}=\frac{-2 \sum_{i=1}^{N} \log p(i)-2 N}{\sqrt{4 N}} \rightarrow \mathrm{N}(0,1)
$$

where $p(i)$ is the p-value associated with $\left(A D F_{\hat{e}}^{c}(i)\right)$ of the ADF test for the $i$ cross section, where $\rho_{i}$ is the autoregressive parameter of the independent error processes (see equation (9)). The test statistic examines whether $\mathrm{H}_{0}: \rho_{i}=1 \forall i$ against $\mathrm{H}_{\mathrm{A}}: \rho_{i}<1$, for some $i$.

The PANIC approach has a number of useful facets from the perspective of our empirical study. For example, O’Connell (1998) suggests cross sectional correlation causes standard pooled panel tests, such as that of Levin, Lin and Chu (2002), to over reject the null hypothesis of a unit root. However, O'Connell's GLS data transformation requires that the common component is stationary. ${ }^{9}$ This may not always be the case. The PANIC approach is advantageous since the common factors and idiosyncratic components are consistent irrespective of whether they are stationary or not: the unobserved components are estimated by first differencing the data and then accumulating the estimates. Additionally, Jang and Shin (2005) provide Monte Carlo evidence that Bai and Ng's (2004) second generation panel unit root test has preferable statistical properties to tests based on principle components such as Moon and Perron (2004) and Phillips and Sul (2003). Due to the nature of subtracting the factor in Bai and $\mathrm{Ng}$ (2004), there are more stable sizes under cross sectional dependency and also OLS estimation (Jang and Shin, 2005).

\subsection{Panel Estimation with a Stationary Factor}

The Bai and Kao (2006) panel cointegrated regression estimator deals with cross sectional correlation by utilising a factor model approach. In particular, this

\footnotetext{
${ }^{9}$ Indeed SURE is infeasible in a situation in which the time dimension of the panel is less that the cross sectional dimension (i.e. $T<N$ ). We consistently apply a factor approach.
} 
approach uses principle components and then the Fully Modified estimator of Phillips and Hansen (1990).

The model is based on the following equation:

$$
y_{i t}=\alpha_{i}+\beta x_{i t}+e_{i t}, \quad i=1, \ldots, N ; t=1, \ldots, T .
$$

In this model $y_{i t}$ is $1 \times 1, \beta$ is $1 \times \mathrm{k}$ is a vector of slope parameters and $\alpha_{i}$ is $1 \times 1$ intercept parameters. Additionally, we have a stationary residual, $e_{i t}$. The nonstationary variables $x_{i t}$ is $1 \times 1$ and set out as follows:

$$
x_{i t}=x_{i t-1}+\varepsilon_{i t}
$$

As such $y_{i t}$ is cointegrated with $x_{i t}$, given the stationarity of the residual. This is the panel approach adopted in, for example, Pedroni (2004). However, this approach assumes that the residual terms are cross sectionally independent. We deal with potential temporal dependence in our panel estimator by adopting a factor model approach. In the factor model the residual errors are set out as follows:

$$
e_{i t}=\lambda_{i}^{\prime} F_{t}+u_{i t}
$$

Here $F_{t}$ and $\lambda_{i}$ are the common factor and factor loadings respectively. The error term $u_{i t}$ in equation (13) is the idiosyncratic component of the residual error in equation (6). The parameters and long-run covariance matrix are estimated recursively, until convergence is reached, using a Continuously-updated Fully Modified (CupFM) estimator (see Bai and Kao, 2006, and Westerlund, 2007). According to Monte Carlo evidence presented in Bai and Kao (2006) OLS has non-negligible bias in comparison to CupFM.

\subsection{Panel Estimation with Nonstationary Factor}

Bai, Kao and $\mathrm{Ng}$ (2007) provide an estimator of a panel cointegrating model with cross sectional dependence generated by stochastic trends. This has an advantage 
over Bai and Kao (2006), since it does not make the restrictive assumption of factor stationarity in equation (13), which has substantial implications for the modelling approach pursued in this paper. Bai et al. (2007) construct two estimators that jointly estimate parameter coefficients and stochastic trends: Continuously-updated and Bias Corrected (CupBC) and Continuously-updated and Fully Modified (CupFM). Monte Carlo results from Bai, Kao and $\mathrm{Ng}$ (2007) suggest that CupBC and CupFM have good finite sample properties and are distinctly superior in terms of mean bias in all cases considered compared to Fixed Effects. As $T$ increases we see bias reduction in CupBC and CupFM, but no bias reduction as we increase $N .^{10}$

\section{Results}

\subsection{Data}

Using annual data, we analyze debt sustainability for fifteen industrial countries during the period of 1978 and 2005 and for twenty-seven emerging markets during 1990 and 2005. The data for industrial countries comes from the OECD Economic Outlook and Statistical Compendium data set and consists of primary government balances as percent of GDP and gross government debt as a percent of GDP. We have data between 1978 and 2005 for 15 countries: Austria, Belgium, Canada, France, Germany, Greece, Ireland, Italy, Netherlands, Norway, Portugal, Spain, Sweden, UK and US.

The data on emerging markets are from Budina and Fiess (2004), extended and updated with the help of official statistics and IMF and World Bank country desk officers. The 27 countries include: Argentina, Brazil, Bulgaria, Chile, China,

\footnotetext{
${ }^{10}$ We consider whether we have a cointegrating relationship between $y_{i t}$ and $x_{i t}$ in equation (11) by applying Bai and Ng's (2004) PANIC to the regression. If both the factor and residual $u_{i t}$ are stationary in equation (13) then we can utilise Bai and Kao (2006). However, if the factor $F_{t}$ is nonstationary and the residual $\underline{u}_{i t}$ is stationary then Bai, Kao and $\mathrm{Ng}$ (2007) is the appropriate approach to estimating equation (11).
} 
Colombia, Costa Rica, Ecuador, Hungary, Indonesia, India, Jamaica, Jordan, Korea, Malaysia, Mexico, Morocco, Nigeria, Pakistan, Panama, Peru, Philippines, Poland, South Africa, Turkey, Uruguay and Venezuela.

Our cross sectional and time dimension is ideally suited to a panel approach. We additionally have a reasonable span of data at least sixteen years, which is more important according to Shiller and Perron (1985) than the frequency of the data, and this of course is complemented by the cross sectional dimension of our panel data set. This is also the approximate size of data set from Mendoza and Ostry (2007) using an approach that does not consider the stationarity properties of the data. ${ }^{11}$

\section{$<$ Insert Table 1 here $>$}

\subsection{Industrial Countries Results}

We first pre-test the industrial countries debt and primary surplus data for nonstationarity using the Bai and Ng (2004) PANIC approach. As already mentioned, PANIC uses a factor structure to take account of cross sectional correlation in panels introduced by common shocks. The time series properties of the data are important in a study of fiscal sustainability, as noted in Trehan and Walsh (1991) and Bohn (1998).

Table 1 suggests that both primary surplus and debt have nonstationary components for industrial countries. In particular, industrial countries' debt $\left(b_{i t}\right)$ has a nonstationary factor and idiosyncratic component. For the primary surplus $\left(s_{i t}\right)$ there is evidence of nonstationarity of the common factor, but not for the idiosyncratic component. The former is indicative of pervasive nonstationarity and underscores the attractiveness of the factor methodology. Given evidence of primary surplus and debt nonstationarity we can estimate fiscal response functions à la Bohn (1998, 2007),

\footnotetext{
${ }^{11}$ We separate our sample into industrial and emerging market economies following convention and since the two groups did not share a common factor.
} 
although these are conditional upon the evidence of cointegration as the absence of cointegration would imply a spurious relationship. ${ }^{12}$

\section{$<$ Insert Table 2 here $>$}

Explicitly taking account of the time series properties of the data we estimate Bohn (1998) type response functions of the primary surplus on government debt, where a positive and significant coefficient on debt (i.e. $\rho>0$ ) in equation (6) is taken as supportive of fiscal probity. To ensure our results are robust, we report coefficient estimates for $\beta$ from equation (11) based on four different panel estimators: Fixed Effects (FE), Bai and Kao (2005) CupFM and Bai, Kao and Ng (2007) CupFM and CupBC. The fixed effects results are likely to be biased, as they are neither robust to panel nonstationarity nor to cross-sectional dependence, which is evident in our data set (see Table 1). Nevertheless, we report FE for comparison with Mendoza and Ostry (2007), who support fiscal probity for emerging market and industrial countries. ${ }^{13}$ The estimators of Bai and Kao (2005), and Bai, Kao and $\mathrm{Ng}$ (2007) are both robust to panel nonstationarity and cross sectional correlation, but these estimators differ in the way they control for cross-sectional dependence. Bai and Kao (2005), for example, rely on a stationary common factor, while the common factor in Bai et al. (2007) can be nonstationary. As we show below, the latter outcome is the case here. This makes Bai et al. (2007) the appropriate estimator.

\section{$<$ Insert Table 3 here $>$}

\footnotetext{
${ }^{12}$ If our data were stationarity, our results would be conditional upon omitted stationary variables (see Bohn, 1998).

${ }^{13}$ Mendoza and Ostry (2007) find evidence that both industrial countries and emerging market economies primary surplus is positively and significantly related to the level of debt, with a coefficient of approximately 0.04. Overall they find little difference between the conduct of fiscal policy in industrial countries and emerging market economies.
} 
A PANIC test on the difference between the primary surplus and debt (see Table 3) identifies one nonstationary common factor. FE and Bai and Kao (2005) are therefore inappropriate estimators in this case, as the relationship between primary surplus and debt is de-coupled by a nonstationary common factor.

Consequently, we use the Bai et al. (2007) test which allows for the possibility of nonstationary factors in estimating a cointegrating panel regression. In Table 2, we obtain a significant and positive coefficient on the CupBC estimation procedure $(0.018$ and $t=7.3)$. This suggests that fiscal policy is responsive to the level of debt, although the CupBC estimated fiscal response to debt is around half of the level suggested by Mendoza and Ostry (2007).

$<$ Insert Table 4 here $>$

\subsection{Emerging Market Economies Result}

Turning now to the emerging markets data, as in the case of the industrial countries, we first pre-test the data to examine whether there is evidence of nonstationarity, using the Bai and Ng (2004) PANIC test. As can be seen in Table 4, PANIC Panel Unit Root tests on the debt/GDP and primary surplus cannot reject the null of a unit root. In both cases, the nonstationarity originates in the common components of Debt/GDP and primary surplus, highlighting the importance we believe of the nonstationary factor approach. Interestingly the fact that the debt/GDP ratio is also nonstationary is indicative of unsustainable debt, according to the approach of Hamilton and Flavin (1986). ${ }^{14}$

\footnotetext{
${ }^{14}$ Although recall the caveat of Bohn (2007).
} 
The evidence reported in Table 5 for the primary surplus/ debt regression is in line with the studies of Bohn (1998) for the US and Mendoza and Ostry (2007) for emerging market economies which report that an increase in debt/GDP results in a higher primary surplus. However, our estimated results are smaller than those reported in Mendoza and Ostry. Next we use the identified coefficient to test for cointegration by means of the Bai and $\mathrm{Ng}$ (2004) PANIC approach.

\author{
$<$ Insert Table 5 here $>$ \\ $<$ Insert Table 6 here $>$
}

In Table 6 Bai and $\mathrm{Ng}$ (2004) identifies the common factor as nonstationary, while the idiosyncratic component is stationary. While overall we fail to identify cointegration between debt/GDP and primary surplus in a panel setting for emerging market economies, it is interesting to observe that the country-specific factors contribute to fiscal sustainability; it is the common factor, that implies debt is not sustainable in emerging markets, as it display a stochastic trend (i.e. the idiosyncratic element is stationary while the factor is nonstationary).

We believe that this is an important finding, with potentially strong policy implications. The fact that country-specific factors have been working on average towards debt sustainability during the 1990s and the first half of the 2000s, shows that national fiscal policies are broadly in line with requirements for fiscal sustainability; given a continuation of current fiscal policies, the main threat to fiscal sustainability appears not to come from the conduct of fiscal policies, but, rather, from common factors which are beyond the control of an individual country: it is the nonstationarity of the common factor that is interfering with the sustainability of fiscal positions. 
Since 2002 , there has been a surge in global liquidity which has led to an unprecedented compression in emerging market spreads. Amongst others, Hauner and Kumar (2006) link recent improvements in fiscal sustainability in emerging markets to this surge in global liquidity, allowing reduced debt financing. The nonstationarity of this factor implies that the recent rise in global interest rates shows that higher interest rates may soon again lead to a deterioration of fiscal sustainability in these countries. A common factor driving global liquidity would also be in line with the Sudden Stop literature (Reinhart and Calvo, 1999), which was motivated by the fact that after the Russian Crisis, most emerging market economies faced a sharp and general decline in capital flows. In the next section we empirically examine the role that global liquidity plays in determining fiscal sustainability.

The size of the coefficient $\rho$ in the fiscal reaction function (6) suggests that there is an equivalent response of the primary surplus to an increase in debt in both industrial countries and emerging market economies. However, as pointed out by Bohn (2007) the size of $\rho$, which determines by how much the primary surplus increases in response to an increase in debt, may be of different consequence for different countries. Despite a positive fiscal response, countries where the fiscal response exceeds debt service are more sustainable than countries with a fiscal response short of debt service. As such, countries where a larger proportion of government spending is debt service payments may need to respond more substantively to the level of debt, as solvency concerns from private agents may arise more readily. In our sample, in 2005 the debt service of emerging market economies was on average about $65 \%$ higher than those of industrial countries, but average debt was about the same ( $60 \%$ in terms of GDP), as such, a similar fiscal response indicates that emerging market economies are less sustainable. 


\section{Economic Interpretation of Common Factors}

In this section we seek to establish if the common factor of the fiscal reaction functions can be linked to global liquidity. As an example, such contention would be for example consistent with the Original Sin argument from Eichengreen and Hausmann (1999) suggesting fiscal policy in emerging market economies is related to developments in world capital markets: Emerging economies have difficulty issuing debt in domestic currency, at fixed interest rates and in long maturities. Therefore changes in world interest rates are expected to impact on their ability to conduct fiscal policy.

Given that the common-factor is nonstationary we use the Johansen (1988, 2002) approach to test for cointegration. ${ }^{15}$ As a measure of global liquidity we use US interest rate on 10 year US Treasury bonds. As global liquidity would impact debt sustainability through debt service, we additionally study the relationship between the factor and country level debt service data.

In Table 7 we obtain strong evidence of Johansen cointegration between the fiscal reaction function factor and US interest rates, which suggests that changes in world interest rates have an impact on their ability to conduct fiscal policy. We believe this is a powerful result since we have identified that fiscal policy in emerging market economies is conditional upon a common factor and this common factor can be related to US interest rates. We furthermore find that US interest rates are cointegrated with debt service in both industrialised and emerging market economies. Evidence for emerging market economies is slightly stronger (see Appendices A1 and A2). Figure A1 in the appendix further illustrate a close relationship between average

\footnotetext{
15 Gengenbach et al. (2006) also emphasizes a Johansen (1988) cointegrating approach when examining global factors.
} 
debt service and the factor for industrialised countries and emerging market economies. Again, the evidence for emerging market economies appears stronger.

$$
<\text { Insert Table } 7 \text { here }>
$$

\section{Robustness Analysis}

Our results before make use of nonstationarity assumptions in the data and use a nonstationary methodology to identify common behaviour between industrial and emerging market countries. To test whether our results are robust in a different methodology we adopt Arellano and Bond (1991) and Blundell and Bond (1998) Dynamic Panel Data Estimator. This also takes account of potential endogeneity amongst our variables since we use Generalised Method of Moments (GMM) and a systems estimator for our instruments (lagged values of the variables themselves). This approach also adds another dimension to the analysis in the previous section by incorporating an explicit test of the standard neo-classical approach to fiscal policy popularised by Barro (1979). This takes account of government's desire to go into deficit in situations of a temporary downturn in the economy or to a temporary increase in government spending in order to smooth tax rates. We measure temporary declines in government spending using detrended GDP and detrended real government expenditure. Additionally we include temporary increases in government expenditure on interest payments. This can be considered a proxy for interest rate effects in the previous analysis.

$<$ Insert Table 8 here $>$ 
The results from Table 8 reveal important similarities and differences between emerging market and industrial countries. Models overall seem well specified since we have no evidence of second order autocorrelation and the Sargan Test statistic for the appropriateness of the instruments is passed. There is an important role for debt in both industrial countries since they are both significant. We also identify an important role for interest expenditure in both countries, with again both significant. This suggests that both groups of countries respond to debt sustainablity issues. However, there are important differences in terms of responses to temporary fluctuations in output and primary government spending. Industrial countries can combine a concern with debt sustainability with being able to smooth the business cycle ${ }^{16}$ (i.e. the estimated coefficient on government spending is positive indicating industrial countries ability to go into debt when there is a downturn in output) and they also respond optimally to temporary increase in government spending by not adjusting tax rates but by running fiscal deficits. On the other hand emerging market economies do not appear to be able to run deficits when there are downturns in the economy, nor are they able to run deficits when there are temporary increases in government spending, consistent with neoclassical tax smoothing since both these variables are insignificant and have a smaller estimated coefficient. ${ }^{17}$ Our contention is that this is consistent with the difficulties that emerging market economies have in issuing debt. These countries pursue fiscal policies focused on debt sustainability which leaves them little opportunity to pursue the welfare enhancing fiscal policies adopted in industrial countries. The significance of the interest expenditure variables is also consistent with

\footnotetext{
${ }^{16}$ See also Méltiz (2000) for evidence that industrial countries pursue countercyclical fiscal policy.

${ }^{17}$ It is interesting to note that Mendoza and Ostry (2007) find little difference between industrial countries and emerging markets in terms of the statistical significance of temporary output and government spending, although the size of the effect is greatly reduced for emerging market economies. Our GMM estimator which is robust to potential endogeneity in this case may explain the difference in results.
} 
changes in global interest rates having a material impact on the behaviour of emerging market economies. $^{18}$

\section{Conclusion}

This paper examines fiscal sustainability in industrial and emerging market economies, by combining time series tests used in much of the literature (see inter alia Hamilton and Flavin, 1986, and Trehan and Walsh, 1991) with the more economics based approach of Bohn (1998, 2007). The latter emphasizes the relationship between the primary surplus and the level of government debt as an indicator of fiscal sustainability. Our work also has implications for the determinants of fiscal policy in a global context. We believe our approach is sufficiently flexible to rationalise the country and global determinants of fiscal policy.

For both industrial countries and emerging market economies we find evidence of a long-run relationship between primary surplus and debt, once we take account of a common stochastic trend. Moreover we subsequently relate this stochastic trend to global liquidity. While we find that the fiscal sustainability of emerging market economies is highly dependent on global liquidity, industrial countries appear to be affected by this common stochastic trend to a lesser extend. As a result, fiscal policy in emerging markets appears to be driven by the single pursuit of fiscal sustainability, while industrial countries can combine a concern with debt sustainability with a welfare enhancing ability to smooth the business cycle. Unlike emerging market economies, consistent with neoclassical tax smoothing, industrial countries are able to run deficits when there are downturns in the economy or to offset temporary increases in government spending. Our contention is that this is consistent

\footnotetext{
${ }^{18}$ Uribe and Yue (2006) identify that US interest rates have a material impact upon the business cycle of emerging market economies.
} 
with the difficulties that emerging market economies have in issuing debt. These countries pursue fiscal policies focused on debt sustainability which leaves them little opportunity to purse the welfare enhancing fiscal policies adopted in industrial countries. Our results are robust to potential endogeneity between output and government spending since we use adopt a panel GMM.

Our research potentially has strong research implications since there is evidence to indicate that emerging market economies pursue sensible long run fiscal policies. Therefore the fiscal difficulties that they experience may be ameliorated by giving them greater access to capital markets without risking the possibility that these countries consequently adopt unsustainable fiscal policies. ${ }^{19}$

\footnotetext{
${ }^{19}$ See the discussion in Williamson (2003) for a contrast of the respective positions on this topic from Eichengreen and Rogoff. Also see Eichengreen (2007) for a discussion of possible means of allowing emerging market economies access to external capital, through an IMF Reserve Augmentation Line, for example.
} 
Table 1: Industrial Countries’ Unit Root Tests

\begin{tabular}{|l|c|c|}
\hline & $s_{i t}$ & $b_{i t}$ \\
\hline Factor & -2.453 & -2.076 \\
\hline Idiosyncratic & $\mathbf{2 . 0 0 2 *}$ & 1.442 \\
\hline
\end{tabular}

Notes: This table examines whether the primary surplus $\left(s_{i t}\right)$ and debt $\left(b_{i t}\right)$ are nonstationary in industrial countries. Panel data set is for 15 countries and 1978 to $2005(N=15, T=28)$. The data is standardized. An information criterion from Bai and $\mathrm{Ng}$ (2002) suggests a factor is appropriate. Star (*) and bold indicates rejection of the null of unit root at the 5\% significance level. Large negative tests statistics reject the null hypothesis of unit root for the Factor (less than -2.89). Large positive test statistics reject the null of unit root for the idiosyncratic component (greater than 1.64). 
Table 2: Nonstationary Panel Estimation with Factors

\begin{tabular}{|l|c|}
\hline \multicolumn{2}{|l|}{ Model with No Factor } \\
\hline Fixed Effects & $\mathbf{0 . 0 5 4}$ \\
& $\mathbf{( 6 . 2 3 2 )}$ \\
\hline \multicolumn{2}{|l|}{} \\
Model with Stationary Factor \\
\hline Bai and Kao (2006) & $\mathbf{0 . 0 5 9}$ \\
CupFM & $\mathbf{( 1 2 . 9 5 1 )}$ \\
\hline \multicolumn{2}{|c|}{} \\
Model with Nonstationary Factor \\
\hline Bai et al. (2007) & $\mathbf{0 . 0 1 8}$ \\
CupBC & $\mathbf{( 7 . 2 8 7 )}$ \\
\hline Bai et al. (2007) & $\mathbf{0 . 0 3 9}$ \\
CupFM & $\mathbf{( 1 2 . 3 4 1 )}$ \\
\hline
\end{tabular}

Notes: Panel data set is 1978 to $2005(N=15, T=28)$. Estimation results are based on equation (15) $s_{i t}=\alpha_{i}+\rho d_{i t}+\lambda_{i} F_{t}$, where a factor $\left(F_{t}\right)$ is included. t-statistics in parentheses and in bold with a star $\left(^{*}\right)$ if significant at the $5 \%$ level. An information criterion from Bai and $\mathrm{Ng}$ (2002) suggests a factor is appropriate. Bai and Kao (2006) continuously updated fully modified (CupFM) estimator has a stationary factor. Bai et al. (2007) continuously bias corrected CupBC and CupFM has a nonstationary factor. 
Table 3: Industrial Countries' Solvency Test

\begin{tabular}{|c|c|c|}
\hline \multirow{2}{*}{} & \multicolumn{2}{|c|}{$s_{i t}=\alpha_{i}+0.018 d_{i t}$} \\
\cline { 2 - 3 } & Factor & Idiosyncratic \\
\hline $1979-2005$ & -2.629 & $\mathbf{2 . 3 2 8 *}$ \\
\hline $1991-2005$ & $-3.536 *$ & $\mathbf{4 . 5 7 0}^{*}$ \\
\hline
\end{tabular}

Notes: Panel data set is for fifteen countries and 1979 to $2005(N=15, T=27)$. An information criterion from Bai and $\mathrm{Ng}(2002)$ suggests a factor is appropriate. Star $(*)$ and bold indicates rejection of the null of unit root at the $5 \%$ significance level. Large negative tests statistics reject the null hypothesis of unit root for the factor (less than -2.89). Large positive test statistics reject the null of unit root for the idiosyncratic component (greater than 1.64). The data is standardized. Our long run relationship is based on CupBC estimates from Table 2. 
Table 4: Emerging Market Unit Root Tests

\begin{tabular}{|l|c|c|}
\hline & $s_{i t}$ & $b_{i t}$ \\
\hline Factor & -1.493 & -1.817 \\
\hline Idiosyncratic & $\mathbf{1 . 9 5 6 *}^{*}$ & $\mathbf{5 . 4 5 6}^{*}$ \\
\hline
\end{tabular}

Notes: This table examines whether the primary surplus $\left(s_{i t}\right)$ and debt $\left(d_{i t}\right)$ are nonstationary for emerging economies. Bold and a star $(*)$ indicate significant at the 5\% level. An information criterion from Bai and $\mathrm{Ng}$ (2002) suggests a factor is appropriate. We use annual data 1990 to 2005 ( $N=27, T=16)$. 
Table 5: Emerging Market Countries Estimated Fiscal Response Function

\begin{tabular}{|l|l|}
\hline \multicolumn{2}{|l|}{ Model with No Factor } \\
\hline Fixed Effects & $\begin{array}{c}\mathbf{0 . 0 1 5} \\
\mathbf{( 2 . 1 0 )}\end{array}$ \\
\hline \multicolumn{2}{|l|}{ Model with Stationary Factor } \\
\hline Bai and Kao (2006) & $\mathbf{0 . 0 1 8 *}$ \\
CupFM & $\mathbf{( 3 . 7 0 )}$ \\
\hline Model with Nonstationary Factor \\
\hline Bai et al. (2007) & $\mathbf{0 . 0 1 8 *}$ \\
CupBC & $\mathbf{( 3 . 7 9 )}$ \\
\hline Bai et al. (2007) & $\mathbf{0 . 0 1 7}$ \\
CupFM & $\mathbf{( 3 . 6 3 )}$ \\
\hline
\end{tabular}

Notes: This table contains factor model estimation results are based on equation (13) $s_{i t}=\alpha_{i}+$ $\rho d_{i t}+\lambda_{i} F_{t}$, where a factor $\left(F_{t}\right)$ is included. Sample period is 1990 to $2005(N=27, T=16)$. tstatistics in parentheses, start (*) and bold if significant at the 5\% level. Bai and Kao (2006) continuously updated fully modified (CupFM) estimator has a stationary factor. Bai et al. (2007) Continuously updated Bias Corrected (CupBC) and CupFM has a nonstationary factor. 
Table 6: Emerging Market Countries' Solvency Test

\begin{tabular}{|c|c|}
\hline \multicolumn{2}{|c|}{$s_{i t}=\alpha_{i}+0.018 b_{i t}$} \\
\hline Factor & Idiosyncratic \\
\hline-1.505 & $2.232^{*}$ \\
\hline
\end{tabular}

Notes: This table examines whether we have stationary residuals from the estimated cointegrating vector $\left(s_{i t}=\alpha_{i}+0.018 b_{i t}\right)$ obtained from Table 5 and the CupBC estimator. We use a factor model to account for cross sectional correlation. We use an information criterion to identify whether there is a factor or not. The maximum number of factors is one. We use annual data 1991 to $2005(N=27, T=15)$. Star and bold $(*)$ indicates rejection of the null of unit root at the $5 \%$ significance level. 
Table 7 Factor Identification

\begin{tabular}{|c|c|c|c|}
\hline Rank Test & Null Hypothesis & \multicolumn{2}{|c|}{ Cointegration of Factor and US interest rates } \\
\hline $\mathrm{p}-\mathrm{r}$ & $\mathrm{r}$ & $\begin{array}{c}\text { Emerging } \\
\text { Markets }\end{array}$ & $\begin{array}{c}\text { Industrial } \\
\text { Countries }\end{array}$ \\
\hline 2 & $\mathrm{r}=0$ & $\begin{array}{c}\mathbf{1 9 . 3 1 6} \\
{[\mathbf{P}=\mathbf{0 . 0 1 5}]}\end{array}$ & $\begin{array}{c}\mathbf{2 3 . 6 9 6} \\
{[\mathbf{P}=\mathbf{0 . 0 1 4}]}\end{array}$ \\
\hline 1 & $\mathrm{r}=1$ & 2.945 & 7.752 \\
{$[\mathrm{P}=0.422]$} & {$[\mathrm{P}=0.052]$} \\
\hline
\end{tabular}

Notes: Johansen (1988) Trace Test examines whether there is cointegration between a common factor from Bai and $\mathrm{Ng}$ (2004) PANIC and US interest rates (T-Bill rate). The null of cointegrating vectors is given by $\mathrm{r}$ and the number of stochastic trends by p-r. Model selected on the basis of a model reduction procedure and residuals are reasonably well specified. P-values are in square brackets based on simulated critical values and a Bartlett correction from Johansen (2002). Star (*) and bold indicates significant at the $5 \%$ level. 
Table 8: GMM Systems Estimates

\begin{tabular}{|l|c|c|}
\hline & $\begin{array}{c}\text { Emerging } \\
\text { Markets }\end{array}$ & $\begin{array}{c}\text { Industrial } \\
\text { Countries }\end{array}$ \\
\hline Debt & $\mathbf{0 . 0 2 8 *}$ & $\mathbf{0 . 0 1 1}$ \\
& $\mathbf{( 2 . 1 0 )}$ & $\mathbf{( 2 . 4 1 )}$ \\
\hline Output Gap & 0.118 & $\mathbf{0 . 3 0 3}$ \\
& $(1.33)$ & $(\mathbf{2 . 7 7 )}$ \\
\hline Spending Gap & -0.017 & $\mathbf{- 0 . 2 6 9}$ \\
& $(-0.81)$ & $\mathbf{( - 5 . 3 6 )}$ \\
\hline Interest Expenditure & $\mathbf{0 . 0 0 8} *$ & $\mathbf{0 . 0 3 2}$ \\
& $\mathbf{( 2 . 1 3 )}$ & $\mathbf{( 3 . 6 7 )}$ \\
\hline Lagged dependent & $\mathbf{0 . 1 3 9 *}$ & $\mathbf{0 . 5 2 4}$ \\
& $\mathbf{( 2 . 1 5 )}$ & $\mathbf{( 1 3 . 5 0 )}$ \\
\hline & & $-3.01 *$ \\
\hline M1 & $-3.31^{*}$ & -1.07 \\
\hline M2 & -1.88 & 0.488 \\
\hline Sargan Test & 0.883 & . \\
\hline
\end{tabular}

Notes: In this table the dependent variable is primary surplus $\left(p s_{i t}\right)$. M1 and M2 are tests for first order and second order autocorrelation and are asymptotically normal. t-statistics in parentheses are based upon Windmeijer (2005) finite sample corrected standard errors robust to serial correlation and heteroscedasticity. Star $(*)$ and bold indicates significant at the 5\% level. Sargan Test of overidentified restrictions reports p-values (small p-value rejects the validity of the instruments). Year dummies and instruments $\mathrm{t}-3$ and greater are included. 


\section{References}

Afonso, A., (2005) Fiscal sustainability: The unpleasant European case. Finanzarchiv vol. 61, pp. 19-44.

Ahmed, S. and Rogers, J.H. (1995) Government budget deficits and trade deficits: Are present value constraints satisfied in long-term data? Journal of Monetary Economics, vol. 36(2), pp. 351-374.

Andrews, D.W.K. (2005) Cross section regressions with common shocks. Econometrica, vol. 73, pp. 55-1585.

Arghyrou, M.G. and K.B. Luintel (2007) Government solvency: Revisiting some EMU countries. Journal of Macroeconomics, vol. 29, pp. 387-410.

Bai, J. and S. Ng (2002) Determining the Number of Factors in Approximate Factor Models. Econometrica, vol. 70, pp. 191-121.

Bai, J. and S. Ng (2004) A PANIC Attack on Unit Roots and Cointegration. Econometrica, vol. 72, pp. 1127-1177.

Bai, J. and C. Kao (2006) On the Estimation and Inference of a Panel Cointegration Model with Cross-Sectional Dependence, Contributions to Economic Analysis, ed. B. Baltagi, Elsevier, pp. 3-30. 
Bai, J. and C. Kao (2005) On the Estimation and Inference of a Panel Cointegration Model with Cross-Sectional Dependence. In B. Baltagi (ed.), Contributions to Economic Analysis. Amsterdam: Elsevier.

http://www-cpr.maxwell.syr.edu/cprwps/pdf/wp75.pdf

Bai, J., Kao, C. and S. Ng (2007) Panel cointegration with global stochastic trends. Revise and resubmit Journal of Econometrics.

Barro, R.J. (1979) On the Determination of Public Debt. Journal of Political Economy, vol. 87, pp. 940-971.

Barro, R.J. (1986) U.S. Deficits since World War I. Scandinavian Journal of Economics, vol. 88, pp. 195-222.

Blundell, R.W. and S.R. Bond (1998) Initial Conditions and Moment Restrictions in Dynamic Panel Data Models. Journal of Econometrics, vol. 87, pp. 115-43.

Bohn, H. (1998) The Behavior Of U.S. Public Debt And Deficits. Quarterly Journal of Economics, vol. 113, pp 949-963.

Bohn, H. (2007) Are stationarity and cointegration restrictions really necessary for the intertemporal budget constraint? Journal of Monetary Economics, Vol. 54(7), pp. $1837-1847$. 
Breitung, J. and M.H. Pesaran (2007) Unit Roots and Cointegration in Panels, in L. Mátyás, and P. Sevestre, The Econometrics of Panel Data (3rd Edition), Kluwer Academic Publishers.

Budina, N. and N. Fiess (2004) Public Debt and Its Determinants in Market Access Countries: Results from 15 Country Case Studies" PRMED. The World Bank, Washington DC.

Calvo, G.A. (1998) Capital Flows and Capital-Market Crises: The Simple Economics of Sudden Stops. Journal of Applied Economics, vol. 1, pp. 35-54.

Calvo, G.A., Izquierdo A. and E. Talvi (2003) Sudden stops, the real exchange rate and fiscal sustainability: Argentina's lessons. NBER Working Paper No. 9828.

Dailami, M., Masson P. and J.J. Padou (2005) Global Monetary Conditions versus Country-Specific Factors in the Determination of Emerging Market Debt Spreads. World Bank Policy Research Working Paper No. 3626.

Davig, T. and E.M. Leeper (2005) Fluctuating Macro Policies and the Fiscal Theory of the Price Level," with Eric Leeper, NBER Macroeconomics Annual 2006, ed. D. Acemoglu, K. Rogoff, and M. Woodford. Vol. 21, pp. 247-298.

Drudi, F. and Prati, A. (2000) Signaling fiscal regime sustainability. European Economic Review, vol. 44(10), pp. 1897-1930. 
Eichengreen, B. and R. Hausmann (1999) Exchange Rates and Financial Fragility. NBER Working Papers No. 7418.

Eichengreen, B. (2007) A Blueprint for IMF Reform: More than just a Lender. International Finance, vol. 10, pp. 153-175.

Elliott, G., Rothenberg, T.J. and Stock, J.H. (1996) Efficient Tests for an Autoregressive Unit Root. Econometrica, vol. 64, pp. 813-36.

Favero, C. and T. Monacelli (2005) Fiscal Policy Rules and Regime (In)Stability: Evidence from the U.S. IGIER Working Paper 282.

Favero, C. and F. Giavazzi (2007) Debt and the Effects of Fiscal Policy. NBER Working Papers No. 12822.

Fiess, N. (2005) Chile's fiscal rule, in Craig Burnside (Ed.) Fiscal Sustainability in Theory and Practice. World Bank; Washington DC.

Gengenbach, C., Palm, F.C. and J.-P. Urbain (2006) Cointegration Testing in Panels with Common Factors. Oxford Bulletin of Economics and Statistics, vol. 68, pp. 683719.

Hakkio, C.S. and Rush, M. (1991) Cointegration: how short is the long run? Journal of International Money and Finance, vol. 10(4), pp. 571-581, 
Hamilton, J.D. and Flavin, M.D. (1986) On the limitations of government borrowing: a framework for empirical testing. American Economic Review, vol. 76, pp. 808-819.

Hauner, D. and M. Kumar (2005): Financial Globalization and Fiscal Performance in Emerging Markets, IMF Working Paper 05/212.

Hauptmeier, S., Heipertz M. and L. Schuknecht (2006) Expenditure Reform in Industrialised Countries: A Case Study Approach. ECB Working Paper No. 634.

Johansen, S. (1988) Statistical Analysis of Cointegrating Vectors. Journal of Economic Dynamics and Control, vol. 12, pp. 231-254.

Johansen, S. (2002) A Small Sample Correction for the Test of Cointegrating Rank in the Vector Autoregressive Model. Econometrica, vol. 70, pp. 1929-1961.

Kaminsky, G., Reinhart C.M. and C. A. Végh (2004) When it rains, it pours: procyclical capital flows and macroeconomic policy, NBER working paper No. 10780.

Kremers, J.J.M. (1988) Long run limits on the US federal debt. Economics Letters, vol. 28, pp. 259-262.

Levin, A., Lin, C.F. and Chu, C-S.J. (2002) Unit root tests in panel data: Asymptotic and finite sample properties, Journal of Econometrics vol. 108, pp. 1-24. 
MacDonald, R. (1992) Some Tests of the Government's Intertemporal Budget Constraint Using U.S. Data. Applied Economics, vol. 24(12), pp. 1287-92.

Mélitz, J. (2000) Some cross-country evidence about fiscal policy behaviour and consequences for EMU. European Economy Reports and Studies No. 2, pp. 3-21.

Mendoza, E.G. and J.D. Ostry (2007) International Evidence on Fiscal Solvency: Is Fiscal Policy Responsible? NBER Working Paper No. 12947.

Moon, H.R. and B. Perron (2004) Testing for a unit root in panels with dynamic factors. Journal of Econometrics, vol. 122. pp. 81-126.

O’Connell, P.G.J. (1998) The overvaluation of purchasing power parity. Journal of International Economics, vol. 44, pp. 1-19.

Pesaran, M.H. (2007) A Simple Panel Unit Root Test in the Presence of Cross Sectional Dependence. Journal of Applied Econometrics, vol. 22(2), pp. 265-312.

Phillips, P.C.B. and B.E. Hansen (1990) Statistical Inference in Instrumental Variables Regression with I(1) Process. Review of Economics Studies vol. 57, pp. 99125.

Phillips, P.C.B. and D. Sul. (2003) Dynamic Panel Estimation and Homogeneity Testing under Cross Section Dependence. Econometrics Journal, vol. 6(1), pp. 217259. 
Prohl, S. and F. Schneider (2006) Sustainability of Public Debt and Budget Deficit: Panel cointegration analysis for the European Union Member countries, University of Linz, Working Paper No. 0610.

Quintos, C.E., (1995) Sustainability of the deficit process with structural shifts. Journal of Business and Economic Statistics vol. 13, pp. 409-417.

Reinhart, C. and G. Calvo (2000) When Capital Inflows Come to a Sudden Stop: Consequences and Policy Options. MPRA Paper No. 6982.

Reinhart, C.M., Rogoff, K.S. and M.A. Savastano (2003) Debt Intolerance. Brookings Papers on Economic Activity, vol. 67, pp. 1-74.

Shiller, R. and P. Perron (1985) Testing the random walk hypothesis: Power versus frequency of observations. Economics Letters, vol. 18, pp. 381-386.

Stock, J.H. (1987) Asymptotic Properties of Least Squares Estimators of Cointegrating Vectors. Econometrica, vol. 55, pp. 1035-56.

Thams, A. (2007) Fiscal Policy Rules in Practice. SFB 649 Discussion Paper 2007016.

Trehan, B. and Walsh, C.E. (1991) Testing Intertemporal Budget Constraints: Theory and Applications to U.S. Federal Budget and Current Account Deficits. Journal of Money, Credit and Banking, vol. 23(2), pp. 206-23, 
Uribe, M. and V.Z. Yue (2006) Country Spreads and Emerging Countries: Who Drives Whom? Journal of International Economics, vol. 69, pp. 6-36.

Westerlund, J. (2007) Estimating cointegrated panels with common factors and the forward rate unbiasedness hypothesis. Journal of Financial Econometrics, vol. 5, pp. 491-522.

Williamson, J. (2003) Comment on Reinhart, C.M., Rogoff, K.S. and M.A. Savastano (2003) Debt Intolerance. Brookings Papers on Economic Activity, vol. 67, pp. 1-74. 


\section{Appendix}

Table A1: Cointegration between US interest rate and interest rate expenditure on debt/GDP (industrialised countries)

\begin{tabular}{|c|c|c|c|c|c|}
\hline \multicolumn{2}{|c|}{ France } & \multirow[b]{2}{*}{ Eig.Value } & \multirow[b]{2}{*}{ Trace } & \multirow[b]{2}{*}{ Frac95 } & \multirow[b]{2}{*}{ P-Value } \\
\hline p-r & $r$ & & & & \\
\hline 2 & 0 & 0.559 & 19.628 & 17.021 & 0.02 \\
\hline 1 & 1 & 0.071 & 1.609 & 8.179 & 0.765 \\
\hline \multicolumn{3}{|c|}{ Germany } & & & \\
\hline p-r & $r$ & Eig.Value & Trace & Frac95 & P-Value \\
\hline 2 & 0 & 0.497 & 19.231 & 17.283 & 0.025 \\
\hline 1 & 1 & 0.171 & 4.119 & 8.171 & 0.314 \\
\hline \multicolumn{2}{|c|}{ Spain } & & & & \\
\hline p-r & $r$ & Eig.Value & Trace & Frac95 & P-Value \\
\hline 2 & 0 & 0.522 & 21.434 & 16.825 & 0.009 \\
\hline 1 & 1 & 0.211 & 5.205 & 8.027 & 0.186 \\
\hline \multicolumn{3}{|c|}{ Portugal } & & & \\
\hline p-r & $r$ & Eig.Value & Trace & Frac95 & P-Value \\
\hline 2 & 0 & 0.699 & 29.576 & 17.256 & 0 \\
\hline 1 & 1 & 0.189 & 4.389 & 7.837 & 0.264 \\
\hline \multicolumn{3}{|c|}{ Belgium } & & & \\
\hline p-r & $r$ & Eig.Value & Trace & Frac95 & P-Value \\
\hline 2 & 0 & 0.578 & 22.722 & 17.793 & 0.008 \\
\hline 1 & 1 & 0.157 & 3.748 & 8.046 & 0.362 \\
\hline \multicolumn{2}{|c|}{ Italy } & & & & \\
\hline p-r & $r$ & Eig.Value & Trace & Frac95 & P-Value \\
\hline 2 & 0 & 0.636 & 25.644 & 17.743 & 0.002 \\
\hline 1 & 1 & 0.143 & 3.383 & 8.018 & 0.409 \\
\hline \multicolumn{3}{|c|}{ Austria } & & & \\
\hline $\mathrm{p}-\mathrm{r}$ & $r$ & Eig.Value & Trace & Frac95 & P-Value \\
\hline 2 & 0 & 0.779 & 47.2 & 17.368 & 0 \\
\hline 1 & 1 & 0.522 & 15.484 & 7.868 & 0.001 \\
\hline \multicolumn{3}{|c|}{ Canada } & & & \\
\hline p-r & $r$ & Eig.Value & Trace & Frac95 & P-Value \\
\hline 2 & 0 & 0.548 & 21.555 & 17.593 & 0.01 \\
\hline 1 & 1 & 0.169 & 4.082 & 0.427 & 0.942 \\
\hline
\end{tabular}


Table A1 (continued)

\begin{tabular}{|c|c|c|c|c|c|}
\hline \multicolumn{2}{|c|}{ USA } & \multirow[b]{2}{*}{ Eig.Value } & \multirow[b]{2}{*}{ Trace } & \multirow[b]{2}{*}{ Frac95 } & \multirow[b]{2}{*}{ P-Value } \\
\hline $\mathrm{p}-\mathrm{r}$ & $r$ & & & & \\
\hline 2 & 0 & 0.499 & 20.155 & 17.073 & 0.016 \\
\hline 1 & 1 & 0.202 & 4.956 & 8.378 & 0.23 \\
\hline \multicolumn{2}{|l|}{ UK } & & & & \\
\hline $\mathrm{p}-\mathrm{r}$ & $r$ & Eig.Value & Trace & Frac95 & P-Value \\
\hline 2 & 0 & 0.456 & 20.472 & 17.465 & 0.015 \\
\hline 1 & 1 & 0.19 & 5.258 & 8.203 & 0.192 \\
\hline \multicolumn{3}{|c|}{ Ireland } & & & \\
\hline p-r & $r$ & Eig.Value & Trace & Frac95 & P-Value \\
\hline 2 & 0 & 0.555 & 23.7 & 17.284 & 0.004 \\
\hline 1 & 1 & 0.235 & 5.893 & 8.322 & 0.149 \\
\hline \multicolumn{3}{|c|}{ Norway } & & & \\
\hline $\mathrm{p}-\mathrm{r}$ & $r$ & Eig.Value & Trace & Frac95 & P-Value \\
\hline 2 & 0 & 0.497 & 26.76 & 17.678 & 0.001 \\
\hline 1 & 1 & 0.41 & 11.624 & 8.242 & 0.009 \\
\hline \multicolumn{3}{|c|}{ Netherlands } & & & \\
\hline $\mathrm{p}-\mathrm{r}$ & $r$ & Eig.Value & Trace & Frac95 & P-Value \\
\hline 2 & 0 & 0.464 & 17.02 & 17.352 & 0.057 \\
\hline 1 & 1 & 0.139 & 3.302 & 8.018 & 0.435 \\
\hline \multicolumn{3}{|c|}{ Sweden } & & & \\
\hline $\mathrm{p}-\mathrm{r}$ & $r$ & Eig.Value & Trace & Frac95 & P-Value \\
\hline 2 & 0 & 0.495 & 21.965 & 17.704 & 0.01 \\
\hline 1 & 1 & 0.271 & 6.952 & 7.9 & 0.088 \\
\hline
\end{tabular}


Table A2: Cointegration between US interest rate and interest rate expenditure on debt/GDP (emerging markets)

\begin{tabular}{|c|c|c|c|c|c|}
\hline \multicolumn{3}{|c|}{ Argentina } & \multirow[b]{2}{*}{ Trace } & \multirow[b]{2}{*}{ Frac95 } & \multirow[b]{2}{*}{ P-Value } \\
\hline $\mathrm{p}-\mathrm{r}$ & $r$ & Eig.Value & & & \\
\hline 2 & 0 & 0.738 & 25.812 & 16.186 & 0.001 \\
\hline 1 & 1 & 0.556 & 9.747 & 7.583 & 0.018 \\
\hline \multicolumn{2}{|c|}{ Brazil } & & & & \\
\hline $\mathrm{p}-\mathrm{r}$ & $r$ & Eig.Value & Trace & Frac95 & P-Value \\
\hline 2 & 0 & 0.947 & 43.545 & 16.417 & 0 \\
\hline 1 & 1 & 0.496 & 8.229 & 7.843 & 0.039 \\
\hline \multicolumn{3}{|c|}{ Bulgaria } & & & \\
\hline $\mathrm{p}-\mathrm{r}$ & $r$ & Eig.Value & Trace & Frac95 & P-Value \\
\hline 2 & 0 & 0.998 & 77.199 & 16.579 & 0 \\
\hline 1 & 1 & 0.456 & 6.704 & 7.736 & 0.078 \\
\hline \multicolumn{2}{|c|}{ China } & & & & \\
\hline$p-r$ & $r$ & Eig.Value & Trace & Frac95 & P-Value \\
\hline 2 & 0 & 0.922 & 36.012 & 16.665 & 0 \\
\hline 1 & 1 & 0.365 & 5.455 & 7.598 & 0.144 \\
\hline \multicolumn{3}{|c|}{ Jamaica } & & & \\
\hline $\mathrm{p}-\mathrm{r}$ & r & Eig.Value & Trace & Frac95 & P-Value \\
\hline 2 & 0 & 0.681 & 22.52 & 15.998 & 0.004 \\
\hline 1 & 1 & 0.52 & 8 & 9857. & 6950. \\
\hline \multicolumn{3}{|c|}{ Malaysia } & & & \\
\hline $\mathrm{p}-\mathrm{r}$ & r & Eig.Value & Trace & Frac95 & P-Value \\
\hline 2 & 0 & 0.854 & 26.957 & 16.311 & 0.001 \\
\hline 1 & 1 & 0.277 & 3.895 & 7.559 & 0.284 \\
\hline \multicolumn{3}{|c|}{ Mexico } & & & \\
\hline $\mathrm{p}-\mathrm{r}$ & r & Eig.Value & Trace & Frac95 & P-Value \\
\hline 2 & 0 & 0.618 & 19.033 & 16.408 & 0.018 \\
\hline 1 & 1 & 0.464 & 7.491 & 7.425 & 0.054 \\
\hline
\end{tabular}


Table A2 (continued)

\begin{tabular}{|c|c|c|c|c|c|}
\hline \multicolumn{2}{|c|}{ Peru } & \multirow[b]{2}{*}{ Eig.Value } & \multirow[b]{2}{*}{ Trace } & \multirow[b]{2}{*}{ Frac95 } & \multirow[b]{2}{*}{ P-Value } \\
\hline p-r & $r$ & & & & \\
\hline 2 & 0 & 0.863 & 34.533 & 16.537 & 0 \\
\hline 1 & 1 & 0.684 & 12.682 & 7.735 & 0.004 \\
\hline \multicolumn{3}{|c|}{ Turkey } & & & \\
\hline p-r & $r$ & Eig.Value & Trace & Frac95 & P-Value \\
\hline 2 & 0 & 0.659 & 19.69 & 16.079 & 0.012 \\
\hline 1 & 1 & 0.432 & 6.786 & 7.253 & 0.073 \\
\hline \multicolumn{3}{|c|}{ Uruguay } & & & \\
\hline p-r & $r$ & Eig.Value & Trace & Frac95 & P-Value \\
\hline 2 & 0 & 0.849 & 25.763 & 16.404 & 0.001 \\
\hline 1 & 1 & 0.363 & 4.953 & 7.712 & 0.188 \\
\hline \multicolumn{3}{|c|}{ Venezuela } & & & \\
\hline p-r & $r$ & Eig.Value & Trace & Frac95 & P-Value \\
\hline 2 & 0 & 0.944 & 36.86 & 16.303 & 0 \\
\hline 1 & 1 & 0.377 & 5.214 & 7.782 & 0.162 \\
\hline \multicolumn{2}{|c|}{ Chile } & & & & \\
\hline $\mathrm{p}-\mathrm{r}$ & $r$ & Eig.Value & Trace & Frac95 & P-Value \\
\hline 2 & 0 & 0.726 & 21.377 & 16.245 & 0.007 \\
\hline 1 & 1 & 0.477 & 7.124 & 7.524 & 0.063 \\
\hline \multicolumn{3}{|c|}{ Hungary } & & & \\
\hline p-r & $r$ & Eig.Value & Trace & Frac95 & P-Value \\
\hline 2 & 0 & 1 & 102.65 & 116.39 & 30.00 \\
\hline 1 & 1 & 0.634 & 11.06 & 27.51 & 20.01 \\
\hline \multicolumn{3}{|c|}{ Pakistan } & & & \\
\hline p-r & $r$ & Eig.Value & Trace & Frac95 & P-Value \\
\hline 2 & 0 & 0.7 & 19.498 & 15.952 & 0.015 \\
\hline 1 & 1 & 0.344 & 5.065 & 7.72 & 0.18 \\
\hline \multicolumn{3}{|c|}{ South Africa } & & & \\
\hline p-r & $r$ & Eig.Value & Trace & Frac95 & P-Value \\
\hline 2 & 0 & 0.999 & 85.246 & 16.216 & 0 \\
\hline 1 & 1 & 0.556 & 8.942 & 7.633 & 0.025 \\
\hline
\end{tabular}


Table A2 (continued)

\begin{tabular}{|c|c|c|c|c|c|}
\hline \multicolumn{3}{|c|}{ Thailand } & \multirow[b]{2}{*}{ Trace } & \multirow[b]{2}{*}{ Frac95 } & \multirow[b]{2}{*}{95 P-Val } \\
\hline p-r & $r$ & Eig.Value & & & \\
\hline 2 & 0 & 1 & 512 & 3515.9 & 0 \\
\hline 1 & 1 & 1 & 231.02 & 867.3 & 0 \\
\hline \multicolumn{3}{|c|}{ Colombia } & & & \\
\hline $\mathrm{p}-\mathrm{r}$ & $r$ & Eig.Value & Trace & Frac95 & P-Value \\
\hline 2 & 0 & 0.988 & 67.194 & 16.451 & 0 \\
\hline 1 & 1 & 0.822 & 18.974 & 7.602 & 0 \\
\hline \multicolumn{3}{|c|}{ Ecuador } & & & \\
\hline p-r & $r$ & Eig.Value & Trace & Frac95 & P-Value \\
\hline 2 & 0 & 0.714 & 18.559 & 16.539 & 0.022 \\
\hline 1 & 1 & 0.254 & 3.517 & 7.549 & 0.334 \\
\hline \multicolumn{3}{|c|}{ Morocco } & & & \\
\hline p-r & $r$ & Eig.Value & Trace & Frac95 & P-Value \\
\hline 2 & 0 & 0.831 & 33.318 & 16.113 & 0 \\
\hline 1 & 1 & 0.631 & 11.951 & 7.5 & 0.005 \\
\hline \multicolumn{3}{|c|}{ Panama } & & & \\
\hline p-r & $r$ & Eig.Value & Trace & Frac95 & P-Value \\
\hline 2 & 0 & 0.597 & 17.445 & 15.98 & 0.033 \\
\hline 1 & 1 & 0.42 & 6.542 & 7.681 & 0.081 \\
\hline \multicolumn{3}{|c|}{ Phillipines } & & & \\
\hline p-r & $r$ & Eig.Value & Trace & Frac95 & P-Value \\
\hline 2 & 0 & 0.694 & 19.603 & 16.598 & 0.015 \\
\hline 1 & 1 & 0.362 & 5.39 & 7.394 & 0.144 \\
\hline \multicolumn{3}{|c|}{ Poland } & & & \\
\hline $\mathrm{p}-\mathrm{r}$ & $r$ & Eig.Value & Trace & Frac95 & P-Value \\
\hline 2 & 0 & 0.904 & 38.103 & 16.872 & 0 \\
\hline 1 & 1 & 0.563 & 9.944 & 7.538 & 0.014 \\
\hline \multicolumn{2}{|c|}{ India } & & & & \\
\hline $\mathrm{p}-\mathrm{r}$ & $r$ & Eig.Value & Trace & Frac95 & P-Value \\
\hline 2 & 0 & 0.958 & 42.787 & 16.507 & 0 \\
\hline 1 & 1 & 0.323 & 4.689 & 7.424 & 0.2 \\
\hline
\end{tabular}


Table A2 (continued)

\begin{tabular}{|c|c|c|c|c|c|}
\hline \multicolumn{3}{|c|}{ Indonesia } & \multirow[b]{2}{*}{ Trace } & \multirow[b]{2}{*}{ Frac95 } & \multirow[b]{2}{*}{ P-Value } \\
\hline p-r & $r$ & Eig.Value & & & \\
\hline 2 & 0 & 0.879 & 33.478 & 16.398 & 0 \\
\hline 1 & 1 & 0.492 & 8.129 & 7.573 & 0.04 \\
\hline \multicolumn{3}{|c|}{ Jordan } & & & \\
\hline $\mathrm{p}-\mathrm{r}$ & $r$ & Eig.Value & Trace & Frac95 & P-Value \\
\hline 2 & 0 & 0.643 & 18.419 & 16.101 & 0.02 \\
\hline 1 & 1 & 0.396 & 6.043 & 7.272 & 0.101 \\
\hline \multicolumn{3}{|c|}{ Costa Rica } & & & \\
\hline p-r & $r$ & Eig.Value & Trace & Frac95 & P-Value \\
\hline 2 & 0 & 0.675 & 22.301 & 16.401 & 0.006 \\
\hline 1 & 1 & 0.373 & 6.546 & 7.752 & 0.085 \\
\hline
\end{tabular}


Figure A1a: US interest rate and Factor for industrialised countries

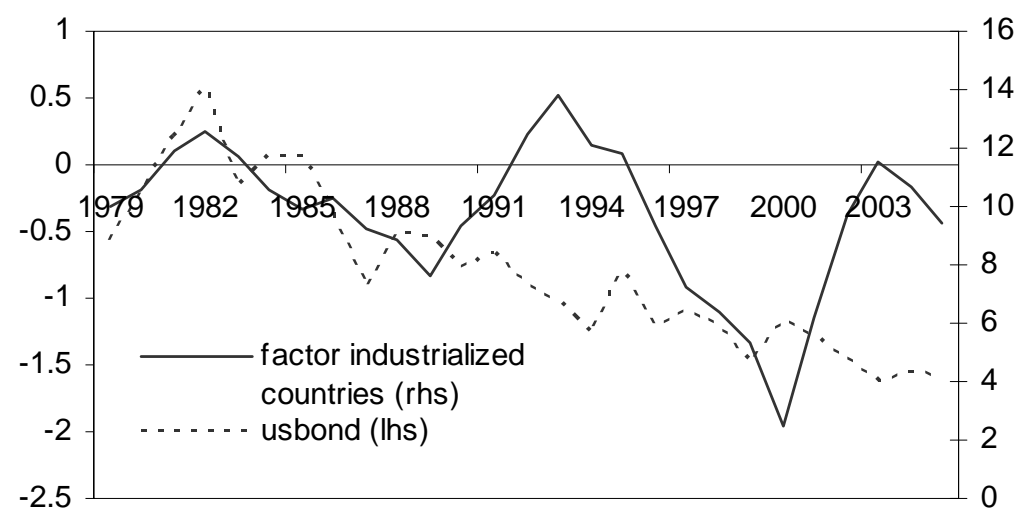

Figure A1b: Average debt service in industrialised countries and Factor for industrialised countries

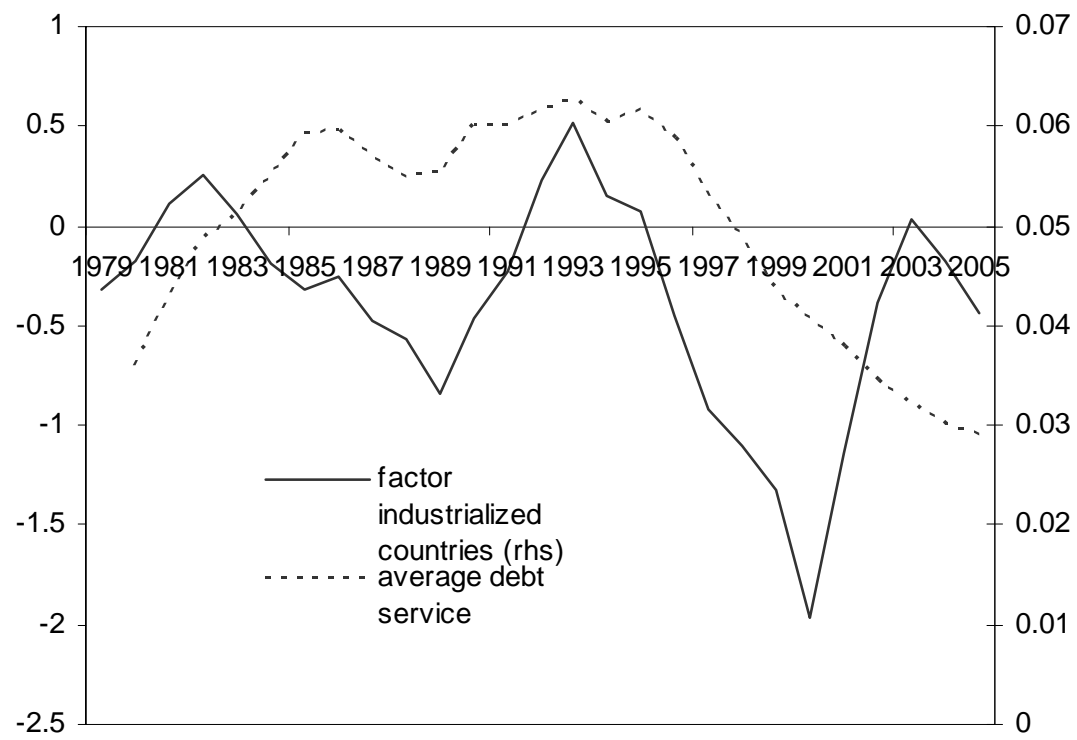


Figure A2a: US interest rate and Factor for emerging markets

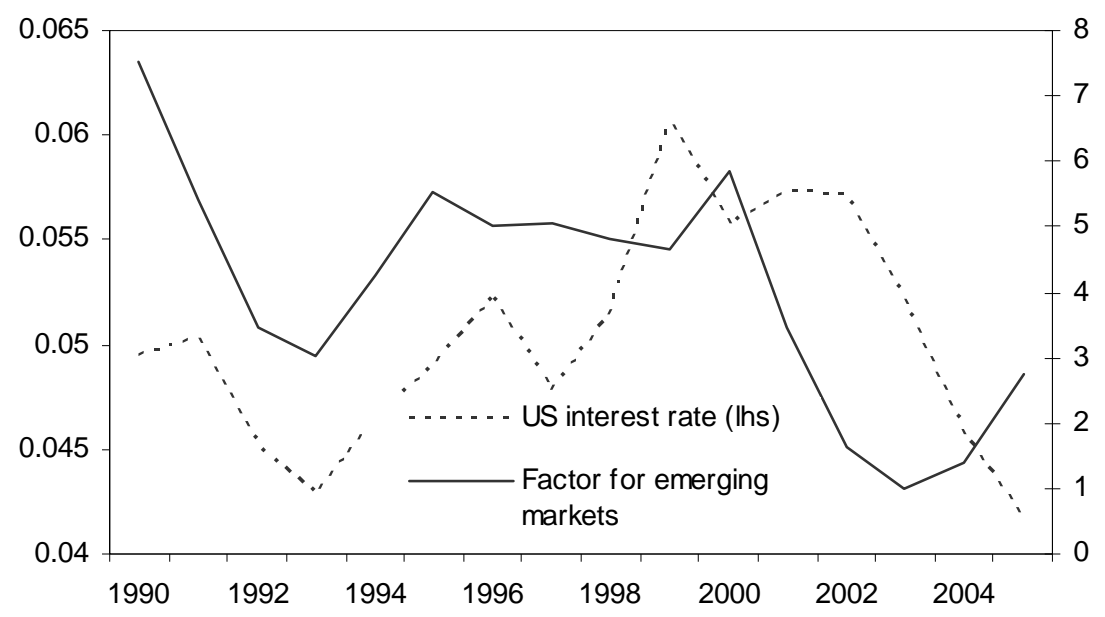

Figure A2b: Average debt service in emerging markets and Factor for emerging markets

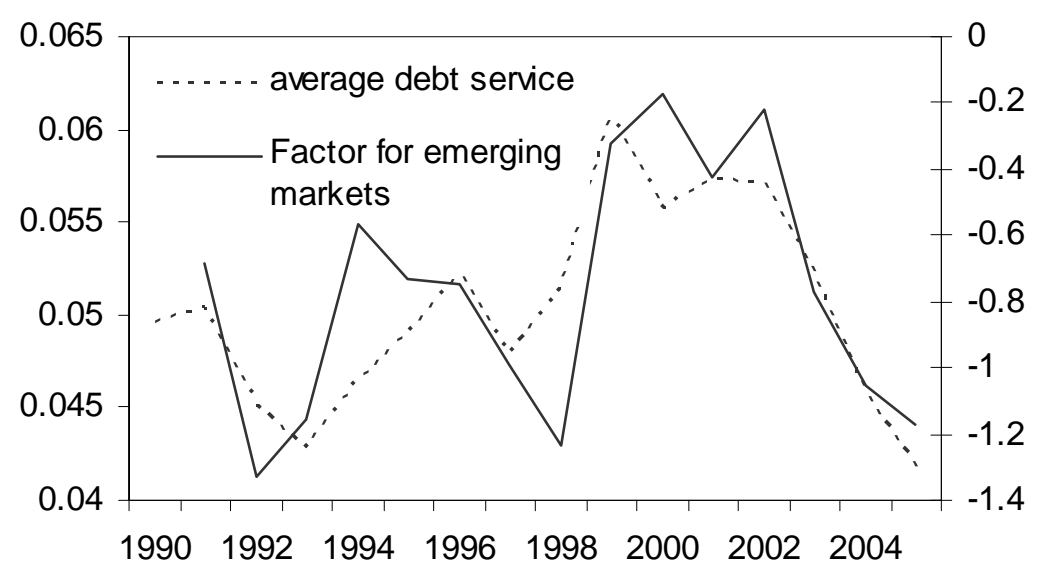

